\title{
UPAYA MENINGKATKAN HASIL BELAJAR DAN KETERAMPILAN PROSES SAINS MELALUI MODEL PEMBELAJARAN BERBASIS MASALAH MENGGUNAKAN VIDEO PEMBELAJARAN PADA MATERI FLUIDA STATIS
}

\author{
Frans Meydy Hutagalung*, Nyoman Rohadi, Irwan Koto
}

\author{
Program Studi Pendidikan Fisika, Fakultas Keguruan dan Ilmu Pendidikan, Universitas Bengkulu \\ Jl. W.R Supratman Kandang Limun, Bengkulu \\ e-mail ${ }^{*}$ franshutagalung05@gmail.com
}

\begin{tabular}{c|c|c|c}
\hline Diterima 19 Juli 2020 & Direvisi 17 Agustus 2020 & Disetujui 22 Agustus 2020 & Dipublikasikan 3 September 2020 \\
\hline \multicolumn{4}{c}{ https://doi.org/10.33369/jkf.3.2.171-180 } \\
\hline
\end{tabular}

\begin{abstract}
ABSTRAK
Penelitian ini merupakan penelitian tindakan kelas pada materi fluida statis yang dilaksanakan dalam empat siklus yang bertujuan untuk mendeskripsikan peningkatan hasil belajar dan keterampilan proses sains. Subjek dalam penelitian ini adalah seluruh siswa kelas XI IPA 1 SMAN 10 Kota Ben gkulu yang berjumlah 28 orang. Hasil penelitian ini menunjukan bahwa hasil belajar siswa pada siklus I daya serapnya sebesar 75,89\% dan ketuntasan belajar siswa sebesar 64,28\% (belum tuntas) serta nilai rata-rata sebesar 75,89, meningkat pada siklus II daya serapnya sebesar 79,64\% dan ketuntasan belajar siswa sebesar 78,57\% (belum tuntas) serta nilai rata-rata sebesar 79,64, kemudian meningkat kembali pada siklus III daya serapnya sebesar $84,11 \%$ dan ketuntasan belajar siswa sebesar 89,29 (tuntas) serta nilai rata-rata sebesar 84,11, dan meningkat lagi pada siklus IV daya serapnya sebesar $88,57 \%$ dan ketuntasan belajar siswa sebesar 100 (tuntas) serta nilai rata-rata sebesar 88,57. Untuk hasil tes keterampilan proses sains skor rata-rata kelas per siklus mengalami peningkatan tiap siklusnya. Pada siklus I diperoleh sebesar 79,46 dengan kategori baik, siklus II diperoleh sebesar 84,64 dengan kategori sangat baik, pada siklus III diperoleh skor rata-rata sebesar 86,61 dengan kategori sangat baik, dan pada siklus IV sebesar 91,25 dengan kategori sangat baik. Berdasaran hasil penelitian dapat disimpulkan bahwa penerapan model pembelajaran berbasis masalah menggunakan video pembelajaran dapat meningkatkan hasil belajar dan keterampilan proses sains siswa pada materi Fluida Statis.
\end{abstract}

Kata Kunci : Hasil Belajar, Keterampilan Proses Sains, Model Pembelajaran Berbasis Masalah.

\begin{abstract}
This research was a classroom action research on static fluid material which was carried out in four cycles which aimed to describe the improvement of learning outcomes and science process skills. The subjects of this study were all students of class XI IPA 1 of SMAN 10 Bengkulu City, totaling 28 people. The results of this study indicated that students learning outcomes in the first cycle absorbed by $75.89 \%$ and students' learning completeness by $64.28 \%$ (incomplete) and an a verage value of 75.89 , increased in the second cycle absorbed by $79,64 \%$ and completeness of student learning by $78.57 \%$ (incomplete) and an average value of 79.64 , then increased again in the third cycle of absorption by $84.11 \%$ and completeness of students learning by 89.29 (complete) and an average value of 84.11, and increased again in the fourth cycle of absorption by $88.57 \%$ and completeness of students learning by 100 (complete) and an average value of 88.57. For the results of the science process skills test, the average score of the class per cycle had increased each cycle. In the first cycle was 79.46 with a good category, the second cycle was 84.64 with a very good category, in the third cycle an average score of 86.61 was obtained with an excellent category, and in the IV cycle it was 91.25 with very good category. Based on the results of the study it could be concluded that the application of problem-based learning models using learning videos can improve students learning outcomes and science process skills on Static Fluid material.
\end{abstract}

Key words: Learning Outcomes, Science Process Skills, Problem Based Learning Model. 


\section{PENDAHULUAN}

IPA adalah suatu kumpulan teori yang sistematis, penerapannya secara umum terbatas pada gejala-gejala alam, lahir dan berkembang melalui metode ilmiah seperti observasi dan eksperimen serta menuntut sikap ilmiah seperti rasa ingin tahu, terbuka dan jujur(1). Tujuan pembelajaran IPA Fisika di SMA adalah untuk mendidik siswa agar memiliki kemampuan mengembangkan kemampuan bernalar dalam berpikir analisis induktif dan deduktif dengan menggunakan konsep dan prinsip fisika untuk memahami berbagai peristiwa alam dan untuk menyelesaikan masalah, baik secara kualitatif maupun kuantitatif'(2). Karena dalam pembelajaran fisika dituntut untuk memahami konsep dan hukumhukumnya, maka pembelajaran fisika hendaknya dibuat semenarik mungkin dengan menggunakan model dan metode yang sesuai dengan materi.

Model Problem Based Learning merupakan pembelajaran yang penyampaiannya dilakukan dengan cara menyajikan sesuatu permasalahan, mengajukan pertanyaan-pertanyaan, memfasilitasi penyelidikan, dan membuka dialog. Permasalahan yang dikaji hendaknya merupakan permasalahan kontekstual yang ditemukan oleh peserta didik dalam kehidupan sehari-hari(3). Model Problem Based Learning meliputi pengajuan pertanyaan atau masalah, memusatkan pada keterkaitan antar disiplin, penyelidikan autentik, kerja sama dan menghasilkan karya serta peragaan(4). Pembelajaran berbasis masalah, antara lain bertujuan untuk membantu siswa mengembangkan keterampilan berfikir dan keterampilan pemecahan masalah(5). Model Problem Based Learning adalah proses pembelajaran yang menggunakan masalah yang dapat disampaikan dikehidupan nyata yang melibatkan siswa dan guru dalam pembelajaran untuk membuat berfikir tinggi siswa mengembangkan keterampilan berpikir dengan pemecahan masalah melalui proses berpikir seperti menemukan pengetahuan baru, sehingga siswa dalam membangun sendiri konsep, hukum, maupun teori tentang suatu permasalahan.

Keterampilan Proses Sains adalah seluruh keterampilan ilmiah yang digunakan untuk menemukan konsep atau prinsip, atau teori dalam rangka mengembangkan konsep yang telah ada atau menyangkal penemuan sebelumnya(6). Keterampilan Proses Sains merupakan langkah pendekatan pembelajaran yang diringkas menjadi 5M (mengamati, menanya, menalar, menyimpulkan dan mengkomunikasikan) untuk mengajarkan mata pelajaran apapun dalam penerapan kurikulum 2013(7). Dalam penelitian ini, KPS yang akan menjadi tolak ukur ada 5 yaitu keterampilan melakukan pengamatan (observasi), keterampilan mengajukan pertanyaan, keterampilan membuat hipotesis, keterampilan melaksanakan percobaan serta keterampilan berkomunikasi. Kelima keterampilan tersebut disesuaikan dengan kegiatan pembelajaran yang dilakukan sesuai dengan model PBL.

Hasil belajar adalah sejumlah pengalaman yang diperoleh siswa yang mencangkup ranah kognitif, afektif, dan psikomotorik. Belajar tidak hanya penguasaan konsep teori mata pelajaran saja, tetapi juga penguasaan kebiasaan, persepsi, kesenangan, minat-bakat, penyesuaian sosial, macammacam keterampilan, cita-cita, keinginan dan harapan(8). Hasil belajar merupakan invariabel atau perubahan perilaku atau sikap siswa akibat belajar dengan diberikan rangsangan melalui kegiatan pembelajaran untuk mengetahui sejauh mana siswa berhasil mencapai tujuan pembelajaran dan memperoleh perubahan perilaku atau sikap setelah proses pembelajaran(9). Kreativitas merupakan kemampuan kognitif tertinggi menggantikan kemampuan evaluasi. Kreativitas adalah kemampuan untuk mengkreasi atau mencipta, yaitu kemampuan yang dipandang paling sulit/tinggi dibanding kemampuan kognitif lainnya(10).

Berdasarkan hasil observasi yang telah dilakukan di SMAN 10 Kota Bengkulu di kelas XI IPA1 ditemukan beberapa fakta bahwa: a) Proses pembelajaran yang diterapkan masih belum efektif, b) Pembelajaran yang digunakan masih sering menggunakan pembelajaran yang berpusat pada guru dengan cara guru memberikan materi secara monoton dari awal sampai akhir pembelajaran, c) Sarana dan prasarana yang tersedia disekolah masih belum dimanfaatkan secara optimal dalam proses pembelajaran, d) Hasil belajar siswa tergolong rendah, e) Keterampilan Proses Sains yang dimiliki siswa masih tergolong rendah. 
Pembelajaran yang menarik ketika siswa dapat menerima proses pelajaran dengan rasa ingin tahu yang tinggi. Untuk menjadikan pembelajaran menjadi menarik bagi siswa dapat dilakukan dengan berbagai cara, salah satunya dengan menggunakan media pembelajaran dalam bentuk media interaktif. Media ini dapat disajikan dengan cara memberikan materi ajar melalui teks, simulasi, animasi, suara dan gambar yang menyerupai aslinya(11). Dengan memanfaatkan media ini, model PBL ini diterapkan dengan menggunakan video pembelajaran YouTube agar dapat menciptakan pembelajaran yang lebih menarik dan menyenangkan serta menghindari siswa dari rasa bosan. Penerapan model PBL dengan menggunakan video pembelajaran YouTube dapat dijadikan salah satu upaya perbaikan proses pembelajaran yang dapat mengubah suasana belajar agar siswa lebih banyak terlibat dalam proses pembelajaran terutama dalam pemecahan masalah. Dengan adanya keterlibatan siswa dalam proses pembelajaran akan memudahkan mereka memahami konsep-konsep yang dipelajari karena mereka mengalami sendiri apa yang dipelajarinya, sehingga diharapkan hasil belajar dan keterampilan sains yang dimiliki siswa dapat meningkat.

Adapun penelitian yang dilakukan Dian Marta Putra yang berjudul "Upaya Meningkatkan Hasil Belajar dan Sikap Ilmiah melalui Problem Based Learnig Model dengan Pendekatan Saintifik Berbantu Media Animasi Pada Konsep Suhu dan Kalor di Kelas X IPA 6 SMAN 2 Arga Makmur" menyatakan bahwa penerapan model pembelajaran Problem Based Learning menggunakan media animasi dapat meningkatkan hasil belajar siswa disetiap siklusnya (12). Berbeda dengan penelitian yang penulis lakukan yaitu menggunakan media berupa video pembelajaran YouTube.

Oleh karena itu perlu dilakukannya penelitian yang berjudul "Upaya Meningkatkan Hasil Belajar Dan Keterampilan Proses Sains Melalui Model Pembelajaran Berbasis Masalah Menggunakan Video Pembelajaran Pada Materi Fluida Statis”. Adapun rumusan masalah dalam penelitian ini adalah (1) Bagaimana penerapan model pembelajaran berbasis masalah dengan menggunakan video pembelajaran YouTube dapat meningkatkan hasil belajar siswa pada materi Fluida Statis di kelas XI IPA 1 SMAN 10 Kota Bengkulu? (2) Bagaimana penerapan model pembelajaran berbasis masalah dengan menggunakan video pembelajaran dapat meningkatkan keterampilan proses sains pada materi Fluida Statis di kelas XI IPA 1 SMAN 10 Kota Bengkulu?

\section{METODOLOGI PENELITIAN}

Jenis penelitian yang digunakan adalah Penelitian Tindakan Kelas (Classroom Action Research). Jenis penelitian yang dilakukan dengan tujuan untuk memperbaiki atau meningkatkan hasil belajar dan keterampilan proses sains yang dimiliki oleh peserta didik. Pada penelitian ini dilakukan proses pembelajaran fisika dengan menggunakan model Pembelajaran Berbasis Masalah (Problem Based Learning). Subjek dalam penelitian ini adalah siswa kelas XI IPA1 SMAN 10 Kota Bengkulu Semester I tahun 2019/2020 yang berjumlah 28 orang, yang terdiri dari 9 orang laki-laki dan 19 orang perempuan.

Penelitian ini dilaksanakan dalam empat siklus. Setiap siklus pada penelitian tindakan kelas terdiri dari empat langkah setiap siklusnya, yaitu a) Tahap perencanaan (Planing), b) Tahap pelaksanaan tindakan (Acting), c) Tahap pengamatan (Observating), d) Tahap refleksi (Reflection).

Instrumen yang digunakan dalam penilitian ini berupa tes hasil belajar dan penilaian keterampilan proses sains setiap siklus. Sebelum instrument digunakan terlebih dahulu dilakukan validasi isi. Validitas isi adalah validitas/tingkat kelayakan yang terkait dari isi sebuah instrumen. Tahap validitas isi pada penelitian ini yaitu, a) terlebih dahulu soal dikoreksi oleh dosen Pendidikan Fisika b) saran/koreksi digunakan sebagai bahan revisi soal, dan c) soal yang telah direvisi digunakan pada penelitian tiap siklusnya.

Teknik pengumpulan data yang digunakan adalah menggunakan data tes dan data keterampilan proses sains. Lembar pengetahuan berupa tes essay yang diberikan kepada siswa setelah siswa mengikuti pembelajaran dengan model PBL pada akhir pembelajaran setiap siklusnya. Tes ini diisi oleh 
siswa agar dapat melihat apakah pembelajaran dikatakan berhasil dan tuntas serta analisis peningkatan hasil belajar setiap siklusnya. Data yang diambil sesuai jumlah siswa yang hadir pada saat penelitian Untuk lembar tes keterampilan proses sains teknik pengumpulan data yang digunakan adalah tes tertulis berupa tes essay untuk mengukur keterampilan siswa pada saat pembelajaran. Tes ini diisi oleh siswa setelah proses pembelajaran di setiap siklus.

Teknik analisis data yang digunakan yaitu menggunakan analisis data penilaian hasil belajar kognitif dan analisis data penilaian keterampilan proses sains. Data tes pengetahuan dianalisa dengan menggunakan rata-rata nilai tes yang dilakukan diakhir setiap siklus. Untuk memperoleh rata-rata tersebut dapat digunakan rumus:

$$
x=\frac{\Sigma x i}{n}
$$

dengan $\mathrm{x}$ adalah nilai rata-rata, $\Sigma x i=$ jumlah nilai siswa, $\mathrm{n}=$ jumlah siswa. Daya serap klasikal menyatakan tingkat kemampuan penguasaan konsep siswa yang diperoleh dari tes pengetahuan yang diukur dengan rumus :

$$
D S=\frac{N S}{S X N I} X 100 \%
$$

dengan DS = daya serap klasikal, $\mathrm{NS}=$ jumlah nilai seluruh siswa, $\mathrm{S}=$ jumlah siswa, $\mathrm{NI}=$ nilai ideal. Ketuntasan belajar dapat dicari menggunakan rumus:

$$
K B=\frac{N \prime}{N} x 100 \%
$$

dengan $\mathrm{KB}=$ Ketuntasan Belajar, $\mathrm{N}^{\prime}=$ Jumlah siswa yang skornya $\geq 75, \mathrm{~N}=$ Jumlah siswa(13).

Data keterampilan proses sains dianalisis dengan menghitung peningkatan nilai di setiap aspek keterampilan. Penilaian untuk aspek keterampilan ini ditentukan dengan cara sebagai berikut:

$$
\text { Nilai }=\frac{\text { Jumlah Skor }}{\text { Jumlah Skor Maksimum } x \text { Jumlah Siswa }} \times 100
$$

Dari perhitungan nilai tersebut, dapat ditentukan predikat capaian tiap aspek keterampilan proses sains seperti pada Tabel 1. di bawah ini :

Tabel 1. Kriteria Predikat Pencapaian Kompetensi KPS

\begin{tabular}{cc}
\hline Skala & Predikat \\
\hline $81 \leq \mathrm{KPS} \leq 100$ & Sangat Baik (A) \\
$61 \leq \mathrm{KPS} \leq 80$ & Baik (B) \\
$41 \leq \mathrm{KPS} \leq 60$ & Cukup (C) \\
$21 \leq \mathrm{KPS} \leq 40$ & Kurang (D) \\
$0 \leq \mathrm{KPS} \leq 20$ & Sangat Kurang (E) \\
\hline
\end{tabular}

(14).

\section{HASIL DAN PEMBAHASAN}

\subsection{Hasil Belajar dalam Empat Siklus}

Hasil belajar diukur dengan menggunakan tes akhir tiap siklus. Tes soal ini berfungsi untuk mengetahui kemampuan atau pemahaman konsep siswa terhadap materi yang telah dipelajari tiap siklusnya. Empat siklus yang telah dilaksanakan ternyata terjadi peningkatan tes hasil belajar siswa setiap siklusnya seperti yang diperlihatkan pada Gambar 1. 


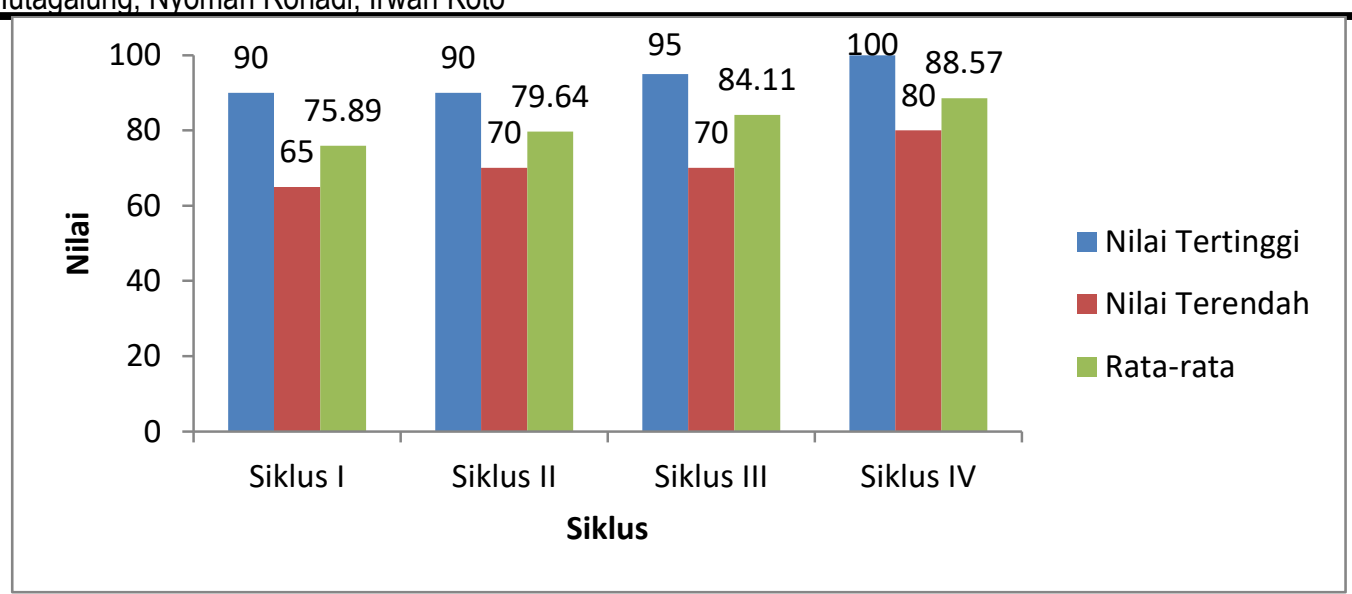

Gambar 1. Grafik Nilai Hasil Belajar Siswa

Gambar 1 menunjukkan nilai rata-rata pada siklus I sebesar 75,89 dengan nilai tertinggi sebesar 90 dan nilai terendah sebesar 65 , untuk nilai rata-rata pada siklus II sebesar 79,64 dengan nilai tertinggi sebesar 90 dan nilai terendah sebesar 70, untuk nilai rata-rata pada siklus III sebesar 84,11 dengan nilai tertinggi sebesar 95 dan nilai terendah sebesar 70, dan untuk nilai rata-rata pada siklus IV sebesar 88,57 dengan nilai tertinggi sebesar 100 dan nilai terendah sebesar 80 . 2.

Untuk peningkatan yang terjadi pada daya serap dan ketuntasan belajar dapat dilihat pada Gambar

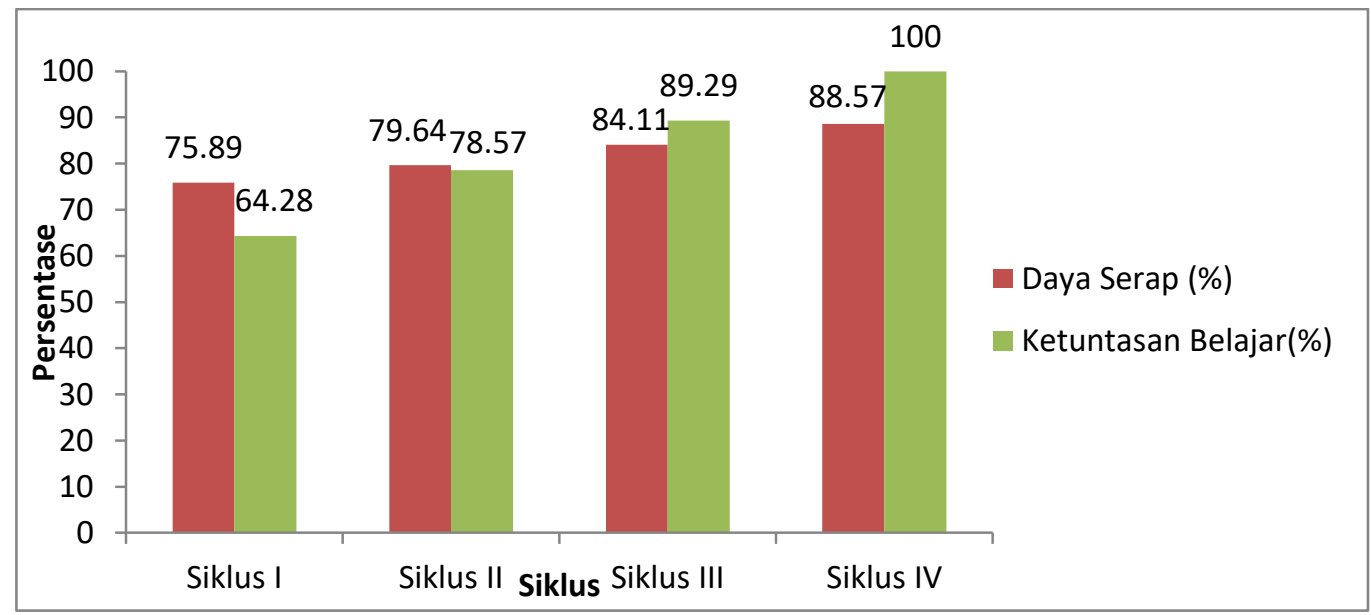

Gambar 2. Grafik Daya Serap dan Ketuntasan Belajar

Berdasarkan Gambar 2, siklus I didapatkan daya serap sebesar 75,89\% dan ketuntasan belajar sebesar $64,28 \%$, pada siklus II didapatkan daya serap sebesar 79,64\% dan ketuntasan belajar sebesar 78,57\%, pada siklus III didapatkan daya serap sebesar 84,11\% dan ketuntasan belajar sebesar 89,29\%, pada siklus IV didapatkan daya serap sebesar $88,57 \%$ dan ketuntasan belajar sebesar $100 \%$.

\subsection{Keterampilan Proses Sains dalam empat siklus}

Keterampilan Proses Sains diukur dengan menggunakan tes akhir tiap siklus. Tes soal ini berfungsi untuk mengetahui keterampilan proses sains siswa terhadap percobaan yang telah dilakukan tiap siklusnya. Empat siklus yang telah dilaksanakan ternyata terjadi peningkatan tes keterampilan proses sains siswa setiap siklusnya seperti yang diperlihatkan pada Gambar 3. 


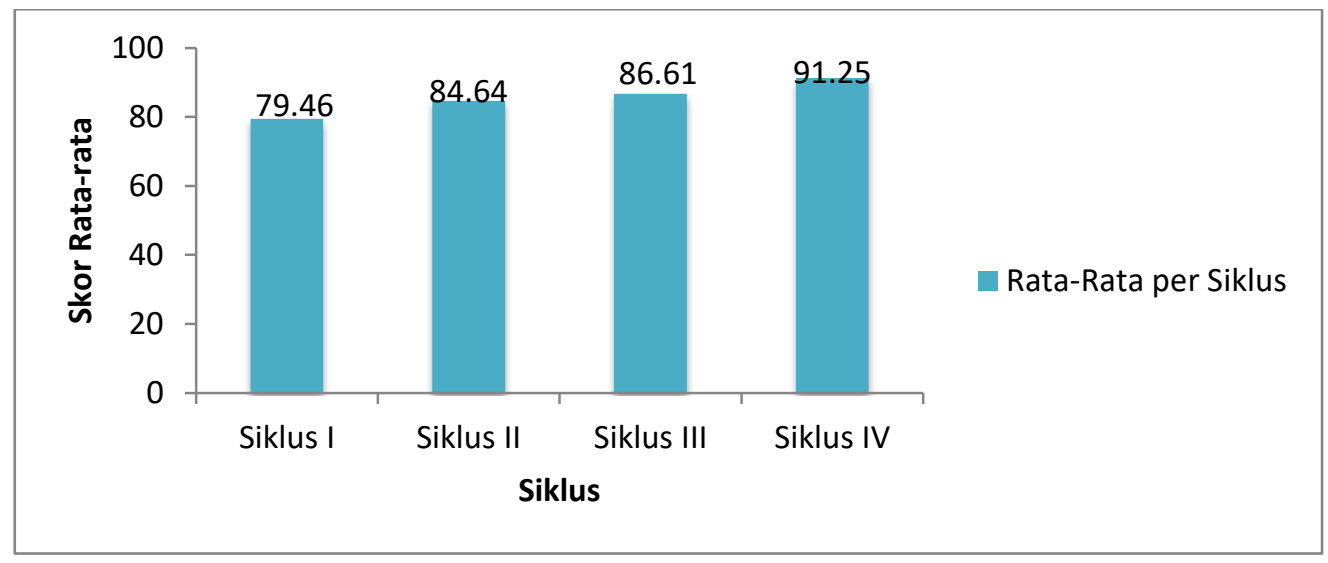

Gambar 3. Grafik Rata-rata KPS per Siklus

Gambar 3 menunjukkan nilai rata-rata KPS pada siklus I sebesar 79,46, untuk nilai rata-rata KPS pada siklus II sebesar 84,64, untuk nilai rata-rata KPS pada siklus III sebesar 86,61, dan untuk nilai rata-rata KPS pada siklus IV sebesar 91,25.

Untuk hasil penilaian setiap aspek indikator pada tes keterampilan proses sains dapat dilihat pada Gambar 4. dibawah ini:

\begin{tabular}{|c|c|c|c|c|}
\hline 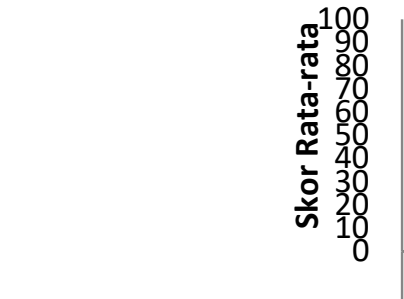 & Siklus I & Siklus II & Siklus III & Siklus IV \\
\hline Mengamati & 89.28 & 77.68 & 98.21 & 91.96 \\
\hline Mengajukan pertanyaan & 77.68 & 78.57 & 92.86 & 80.36 \\
\hline Membuat Hipotesis & 92.43 & 92.85 & 83.93 & 91.07 \\
\hline Melaksanakan Percobaan & 83.93 & 98.21 & 82.14 & 100 \\
\hline Mengkomunikasikan & 64.48 & 71.43 & 76.78 & 92.86 \\
\hline
\end{tabular}

Gambar 4. Grafik Rata-rata KPS tiap Indikator

Berdasarkan Gambar 4, indikator mengamati, pada siklus I sebesar 89,28, pada siklus II sebesar 77,68, pada siklus III sebesar 98,21, pada siklus IV sebesar 91,96. Pada indikator mengajukan pertanyaan, pada siklus I sebesar 77,68, pada siklus II sebesar 78,57, pada siklus III sebesar 92,86, pada siklus IV sebesar 80,36. Pada indikator membuat hipotesis, pada siklus I sebesar 92,43, pada siklus II sebesar 92,85, pada siklus III sebesar 83,93, pada siklus IV sebesar 91,07. Pada indikator melaksanakan percobaan, pada siklus I sebesar 83,93, pada siklus II sebesar 98,21, pada siklus III sebesar 82,14, pada siklus IV sebesar 100 Pada indikator mengkomunikasikan pada siklus I sebesar 64,48, pada siklus II sebesar 71,43, pada siklus III sebesar 76,78, pada siklus IV sebesar 92,86.

\subsection{Pembahasan}

\subsubsection{Hasil Belajar}

Berdasarkan hasil yang tertera dari Gambar 1, terlihat bahwa ada peningkatan dari hasil belajar siswa pada tes akhir siklus setiap siklusnya. Pada siklus I dengan nilai rata-rata hasil belajar siswa sebesar 75,89, artinya siswa telah melebihi KKM yang telah ditetapkan yaitu 75 maka jika dilihat dari nilai rata-rata hasil belajar siswa dapat dikatakan siswa telah tuntas secara klasikal, namun pada siklus I masih ada siswa yang tidak tuntas yaitu sebanyak 10 orang dan 18 orang telah tuntas, sehingga 
Upaya Meningkatkan Hasil Belajar dan Keterampilan Proses Sains Melalui Model Pembelajaran Berbasis Masalah Menggunakan.... Frans Meydy Hutagalung, Nyoman Rohadi, Irwan Koto

membuat ketuntasan belajar siswa masih dibawah $\geq 85 \%$. Siklus I pun hasil belajar belum dapat dikatakan tuntas secara klasikal. Hal ini terjadi karena masih adanya beberapa siswa yang belum mendapatkan nilai yang dikategorikan tuntas.

Begitu juga pada siklus II belum bisa juga dikatakan tuntas secara klasikal walaupun pada siklus II mengalami peningkatan nilai rata-rata hasil belajar siswa sebesar 79,64 yang telah melampui nilai KKM sebesar 75. Hal ini dikarenakan masih ada siswa yang belum tuntas yaitu sebanyak 6 orang dan sebanyak 22 orang telah tuntas yang mengakibatkan hasil dari ketuntasan belajar masih dibawah $\geq 85 \%$. Sehingga secara klasikal, hasil belajar siswa pada siklus kedua belum bisa dikatakan tuntas secara klasikal.

Pada siklus III, hasil belajar siswa sudah bisa dikatakan tuntas secara klasikal karena pada siklus III nilai rata-rata hasil belajar siswa yaitu sebesar 84,11 yang telah melampaui nilai KKM sebesar 75 dan telah melebihi standar ketuntasan belajar yaitu $\geq 85 \%$ sedangkan ketuntasan belajar yang didapatkan pada siklus III meningkat menjadi 89,29. Dengan begitu, pada siklus III hasil belajar siswa telah tuntas secara klasikal.

Pada siklus IV, terjadi peningkatan baik dari nilai rata-rata hasil belajar siswa sebesar 88,57 maupun ketuntasan belajar yang mencapai 100\%. Hal ini berarti bahwa pada siklus IV nilai hasil belajar dari seluruh siswa sudah melampaui nilai KKM sebesar 75. Dan dapat dikatakan bahwa pada siklus IV hasil belajar siswa sudah tuntas secara klasikal.

Berdasarkan Gambar 2, dapat dilihat bahwa terjadi peningkatan baik dari daya serap maupun ketuntasan belajar dari hasil belajar siswa dalam setiap siklusnya. Peningkatan tes hasil belajar siswa ini dapat menggambarkan bahwa terjadi peningkatan pemahaman materi pelajaran dari setiap siklusnya, dikarenakan adanya refleksi atau perbaikan yang dilakukan oleh guru di setiap siklusnya, baik dari segi aktivitas belajar siswa, aktivitas guru maupun contoh-contoh soal yang diberikan pada saat proses pembelajaran berlangsung. Hal ini selaras dengan hasil penelitian Dian Marta Putra (2017) yang berjudul "Upaya Meningkatkan Hasil Belajar dan Sikap Ilmiah melalui Problem Based Learnig Model dengan Pendekatan Saintifik Berbantu Media Animasi Pada Konsep Suhu dan Kalor di Kelas X IPA 6 SMAN 2 Arga Makmur" menyatakan bahwa penerapan model pembelajaran Problem Based Learning menggunakan media dapat meningkatkan hasil belajar siswa disetiap siklusnya. Dapat dilihat dari hasil penelitian yang didapat, yaitu terjadinya peningkatan hasil belajar disetiap siklusnya (12).

\subsubsection{Keterampilan Proses Sains}

Berdasarkan Gambar 3, dapat dilihat bahwa nilai rata-rata siswa pada keterampilan proses sains siswa dari siklus I - siklus IV mengalami peningkatan setiap siklusnya. Pada siklus I didapatkan bahwa nilai tertinggi yang didapatkan siswa untuk tes keterampilan proses sains yaitu sebesar 90 dengan kategori sangat baik (A), dan untuk nilai terendah yang didapatkan siswa untuk tes keterampilan proses sains pada siklus I yaitu sebesar 50 dengan kategori cukup (C). Nilai rata-rata per siklus yang didapatkan oleh siswa untuk tes keterampilan proses sains sebesar 79,46 yang termasuk dalam kategori baik (B). Pada siklus ini, keterampilan proses sains siswa dinyatakan keterampilan dalam aspek mengamati, berhipotesis, dan melakukan percobaan.

Pada siklus II, didapatkan bahwa nilai tertinggi yang didapatkan siswa untuk tes keterampilan proses sains yaitu sebesar 100 dengan kategori sangat baik (A), dan untuk nilai terendah yang didapatkan siswa untuk tes keterampilan proses sains pada siklus II yaitu sebesar 50 dengan kategori cukup (C). Nilai rata-rata per siklus yang didapatkan oleh siswa untuk tes keterampilan proses sains pada siklus II megalami peningkatan yaitu menjadi sebesar 84,64 yang sudah termasuk dalam kategori sangat baik (A). Pada siklus ini, keterampilan proses sains siswa dinyatakan terampil dalam aspek berhipotesis dan merencanakan percobaan yang termasuk dalam kategori sangat baik.

Pada siklus III, didapatkan bahwa nilai tertinggi yang didapatkan siswa untuk tes keterampilan proses sains yaitu sebesar 95 dengan kategori sangat baik (A), dan untuk nilai terendah yang didapatkan siswa untuk tes keterampilan proses sains yaitu sebesar 70 dengan kategori baik (B). Nilai 
rata-rata per siklus yang didapatkan oleh siswa untuk tes keterampilan proses sains pada siklus III mengalami peningkatan yaitu sebesar 86,61 yang termasuk dalam kategori sangat baik (A). Pada siklus ini, keterampilan proses sains siswa dinyatakan terampil dalam aspek mengamati, mengajukan pertanyaan, berhipotesis, dan merencanakan percobaan.

Pada siklus IV, didapatkan bahwa nilai tertinggi yang didapatkan siswa untuk tes keterampilan proses sains yaitu sebesar 100 dengan kategori sangat baik (A), dan untuk nilai terendah yang didapatkan siswa untuk tes keterampilan proses sains pada siklus IV yaitu sebesar 80 dengan kategori sangat baik (A). Nilai rata-rata per siklus yang didapatkan oleh siswa untuk tes keterampilan proses sains pada siklus IV mengalami peningkatan menjadi sebesar 91,25 yang termasuk kedalam kategori sangat baik (A). Pada siklus IV, aspek dari keterampilan proses sains siswa dinyatakan telah terampil semua yaitu dari mulai aspek mengamati, mengajukan pertanyaan, berhipotesis, merencanakan percobaan dan mengkomunikasikan.

Pada indikator mengamati, mengalami kenaikan dan penurunan nilai rata-rata setiap siklusnya. Berdasarkan Gambar 4, dapat dilihat bahwa pada siklus I nilai rata-rata indikator mengamati sebesar 89,28 masuk dalam kategori sangat baik (A), akan tetapi menurun pada siklus II menjadi sebesar 77,68 masuk dalam kategori baik (B) dan meningkat lagi pada siklus III menjadi sebesar 98,21 masuk dalam kategori sangat baik (A), kemudian kembali menurun lagi pada siklus IV menjadi sebesar 91,96 masuk dalam kategori sangat baik (A). Hal ini disebabkan karena siswa melakukan pengamatan belum terlalu disesuaikan dengan materi yang dipelajari.

Pada indikator mengajukan pertanyaan, mengalami kenaikan dari siklus I-siklus III tetapi mengalami penurunan nilai rata-rata pada siklus IV. Berdasarkan Gambar 4.6, dapat dilihat bahwa pada siklus I nilai rata-rata indikator mengajukan pertanyaan sebesar 77,68 masuk dalam kategori baik (B), mengalami peningkatan nilai rata-rata pada siklus II menjadi sebesar 78,57 masuk dalam kategori baik (B) dan meningkat lagi pada siklus III menjadi sebesar 92,86 masuk dalam kategori sangat baik (A), kemudian terjadi penurunan nilai rata-rata pada siklus IV menjadi sebesar 80,36 masuk dalam kategori sangat baik (A). Hal ini disebabkan karena siswa mengajukan pertanyaan belum terlalu disesuaikan dengan materi yang dipelajari.

Pada indikator membuat hipotesis, mengalami penurunan nilai rata-rata dari siklus I-siklus III tetapi mengalami peningkatan nilai rata-rata pada siklus IV. Berdasarkan Gambar 4.6, dapat dilihat bahwa pada siklus I nilai rata-rata indikator membuat hipotesis yaitu sebesar 92,43 masuk dalam kategori sangat baik (A), mengalami penurunan nilai rata-rata pada siklus II menjadi sebesar 92,25 masuk dalam kategori sangat baik (A) dan menurun lagi pada siklus III menjadi sebesar 83,93 masuk dalam kategori sangat baik (A), kemudian terjadi peningkatan nilai rata-rata pada siklus IV menjadi sebesar 91,07 masuk dalam kategori sangat baik (A). Hal ini disebabkan karena siswa dalam membuat hipotesis belum terlalu disesuaikan dengan materi yang dipelajari.

Pada indikator melaksanakan percobaan, mengalami kenaikan dan penurunan nilai rata-rata setiap siklusnya. Berdasarkan Gambar 4.6, dapat dilihat bahwa pada siklus I nilai rata-rata indikator melaksanakan percobaan sebesar 83,93 masuk dalam kategori sangat baik (A), mengalami kenaikan pada siklus II menjadi sebesar 98,21 masuk dalam kategori sangat baik (A), akan tetapi mengalami penurunan nilai rata-rata pada siklus III menjadi sebesar 82,14 masuk dalam kategori sangat baik (A), kemudian kembali meningkat lagi pada siklus IV dan mencapai nilai maksimum yaitu sebesar 100 masuk dalam kategori sangat baik (A). Penurunan nilai rata-rata untuk indikator melaksanakan percobaan terjadi pada siklus II-siklus III tetapi pada siklus IV nilai rata-rata untuk indikator melaksanakan percobaan mencapai nilai maksimum yaitu 100 yang masuk ke dalam kategori sangat baik (A).

Pada indikator mengkomunikasikan, mengalami peningkatan nilai rata-rata setiap siklus nya. Berdasarkan Gambar 4, dapat dilihat bahwa pada siklus I nilai rata-rata indikator mengkomunikasikan sebesar 64,48 masuk dalam kategori baik (B), mengalami penigkatan pada siklus II menjadi sebesar 
71,43 masuk dalam kategori baik (B), mengalami peningkatan lagi nilai rata-rata pada siklus III menjadi sebesar 76,78 masuk dalam kategori baik (B), kemudian mengalami peningkatan lagi pada siklus IV yaitu sebesar 92,86 masuk dalam kategori sangat baik (A). Pada indikator mengkomunikasikan ini, nilai rata-rata nya mengalami peningkatan dari siklus I - siklus IV dan juga jumlah siswa yang tidak tuntas mengalami penurunan. Sehingga pada siklus III dan siklus IV sudah tidak ada lagi siswa yang tidak tuntas.

Dari penjelasan dan penjabaran diatas, maka dapat disimpulkan bahwa proses pembelajaran fisika dengan model PBL menggunakan video pembelajaran dapat meningkatkan hasil dari keterampilan proses sains siswa. Ini dapat dilihat dari nilai rata-rata keterampilan proses sains yang didapatkan di setiap siklusnya yang mengalami peningkatan, dikarenakan adanya refleksi atau perbaikan di setiap siklusnya, baik dari segi aktivitas belajar siswa, aktivitas guru maupun proses praktikum yang dilakukan disetiap siklusnya.

\section{Kesimpulan Dan Saran \\ 4.1 Kesimpulan}

Berdasarkan hasil penelitian yang didapatkan oleh peneliti, maka dapat disimpulkan bahwa penerapan model pembelajaran berbasis masalah (Problem Based Learning) menggunakan video pembelajaran YouTube pada konsep Fluida Statis terhadap Hasil Belajar siswa di kelas XI IPA 1 SMAN 10 Kota Bengkulu mengalami peningkatan setiap siklusnya. Hal ini terlihat pada nilai rata-rata di setiap siklusnya mengalami peningkatan dan juga adanya peningkatan daya serap setiap siklusya.Dengan nilai rata-rata pada siklus I yaitu 75,89, meningkat pada siklus II yaitu 79,64, meningkat kembali pada siklus III yaitu 84,11, dan meningkat lagi pada siklus IV sebesar 88,57.

Penerapan model pembelajaran berbasis masalah (Problem Based Learnig) menggunakan video pembelajaran YouTube pada konsep Fluida Statis terhadap keterampilan proses sains siswa di kelas XI IPA 1 SMAN 10 Kota Bengkulu mengalami peningkatan setiap siklusnya. Hal ini terlihat pada nilai rata-rata disetiap siklusnya mengalami peningkatan dan sudah masuk kedalam kategori sangat baik hingga siklus IV. Untuk setiap indikator telah mengalami peningkatan (terutama pada indikator melaksanakan percobaan dengan nilai rata-rata sebesar 91,07 yang masuk dalam kategori sangat baik (A) dan agak lemah pada indikator mengkomunikasikan dengan nilai rata-rata sebesar 76,39 yang masuk dalam kategori baik (B)).

\subsection{Saran}

Saran-saran yang perlu dikemukakan berdasarkan proses penelitian sampai dengan hasil penelitian adalah sebagai berikut: Proses pembelajaran menggunakan video pembelajaran memakan waktu yang cukup banyak, agar pembelajaran lebih optimal, disarankan kepada guru untuk dapat mengatur waktu selama pelaksanaan pengajaran serta kegiatan praktikum.

Kurangnya respon siswa terhadap kegiatan pembelajaran, maka diharapkan sebelum kegiatan pembelajaran siswa lebih banyak membaca dan mempelajari referensi pelajaran yang berkaitan dengan materi yang akan diajarkan. Sehingga dapat membantu siswa agar dapat membangun pengetahuan awal yang lebih baik.

\section{DAFTAR PUSTAKA}

1. Trianto. Panduan Lengkap Penelitian Tindakan Kelas. Jakarta: Pustakakarya; 2011. 136 p.

2. Istiyono E. Pengembangan Tes Kemampuan Berpikir Tingkat Tinggi Fisika (PysTHOTS) Peserta Didik SMA. J Fis. 2014;2.

3. Sani R. Pembelajaran Saintifik Untuk Implementasi Kurikulum 2013. Jakarta: Bumi Aksara; 2015. 127 p. 
4. Amir M. Inovasi Pendidikan Melalui Problem Based Learning. Jakarta: Kencana; 2009. 29 p.

5. Hosnan M. Pendekatan Saintifik Dan Konsektual Dalam Perjalanan Abad 21. Bogor: Ghalia Indonesia; 2014. 295 p.

6. Rustaman N. Membangun Literasi Sains Peserta Didik. Jakarta: Humaniora; 2011. 123 p.

7. Mulyasa. Pengembangan \& Implementasi Kurikulum 2013. Bandung: Remaja Rosdakarya; 2015. 28 p.

8. Rusman. Belajar Dan Pembelajaran Berbasis Komputer. Jakarta: Rajawali Pers; 2013. 123 p.

9. Riyanto Y. Paradigma Baru Pembelajaran. Jakarta: Prenada Media; 2009. 56 p.

10. Dimyati, Mudjiono. Belajar dan Pembelajaran. Jakarta: Rineka Cipta; 2013. 10-11 p.

11. Rustaman N. Strategi Belajar Mengajar Fisika. Malang: UM Press; 2005. 34 p.

12. Putra DM. Upaya Meningkatkan Hasil Belajar Dan Sikap Ilmiah Melalui Problem Based Learning Model dengan Pendekatan Saintifik Berbantu Animasi Pada Konsep Suhu dan Kalor di Kelas X IPA 6 SMAN 2 Arga Makmur. J PendidikanFisika. 2017;100.

13. Trianto. Panduan Lengkap Penelitian Tindakan Kelas. Jakarta: Pustakakarya; 2009. 241 p.

14. Nismalasari. Penerapan Model Pembelajaran Learning Cycle Terhadap Keterampilan Proses Sains Dan Hasil Belajar Siswa Pada Pokok Bahasan Getar Harmonis. J PendidikanFisika. 2016;4:83. 